\title{
Experiences and Determinants of Contraceptive Use among On-Street Women in Shashemene Town, West Arsi Zone, Ethiopia
}

\author{
Bewunetu Zewude Gebremeskel*, Kedir Usman Geda and Adane Tesfaye Anbesse \\ Department of Sociology, Paradise Valley College, Shashemene, Ethiopia
}

*Corresponding author: Bewunetu Zewude Gebremeskel, Department of Sociology, Paradise Valley College, Shashemene, Ethiopia

\begin{tabular}{|c|c|}
\hline ARTICLE INFO & ABSTRACT \\
\hline 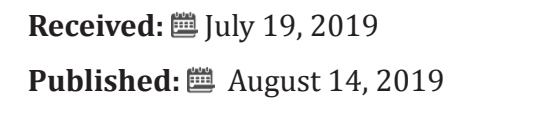 & $\begin{array}{l}\text { The purpose of this research was to assess the use of family planning methods and } \\
\text { determinants of contraceptive use among on-street women in Shashemene town. A cross- } \\
\text { sectional study design was used in which the overall processes of data collection, analysis }\end{array}$ \\
\hline $\begin{array}{l}\text { Citation: RBewunetu Zewude Ge- } \\
\text { bremeskel, Kedir Usman G, Adane Tes- } \\
\text { faye Anbesse. Experiences and Deter- } \\
\text { minants of Contraceptive Use among } \\
\text { On-Street Women in Shashemene Town, } \\
\text { West Arsi Zone, Ethiopia. Biomed J } \\
\text { Sci \& Tech Res 20(4)-2019. BJSTR. } \\
\text { MS.ID.003476. }\end{array}$ & $\begin{array}{l}\text { 2019. } 163 \text { homeless women selected on the basis of purposive sampling procedure } \\
\text { have participated in the study. Both qualitative and quantitative data were collected } \\
\text { using survey and depth interview methods. While quantifiable data were entered into } \\
\text { SPSS version } 20 \text { for further analysis, qualitative data were transcribed, organized, and } \\
\text { narratively presented after finding themes in the data. Knowledge of family planning } \\
\text { methods and the experiences of using one were moderately low among the homeless } \\
\text { women. Whereas } 49.3 \% \text { have ever heard about family planning methods, } 48.6 \% \text { know } \\
\text { the fact that family planning methods can prevent unwanted pregnancies. Moreover, }\end{array}$ \\
\hline $\begin{array}{l}\text { Keywords: - On-Street Women; Contra- } \\
\text { ceptive Methods; Shashemene; Experi- } \\
\text { ences; Determinants }\end{array}$ & $\begin{array}{l}\text { of the homeless women }(41.9 \%) \text {. Furthermore, the use of family planning methods has } \\
\text { been found to be significantly associated to age }(.202, \mathrm{P}<0.05,95 \% \mathrm{CI}) \text {, number of children } \\
(.189, \mathrm{P}<.021,95 \% \mathrm{CI}) \text {, and education }(-.384, \mathrm{P}<0.01,90 \% \mathrm{CI}) \text {. Reproductive health among } \\
\text { the homeless women involves a mix of both promising and weak health seeking behavior } \\
\text { dynamics. Whereas there is a very high demand of contraceptive use, the experience of } \\
\text { using family planning methods is low. Therefore, awareness creation and mobilization } \\
\text { activities need to be undertaken, needless to mention that creating better access to } \\
\text { contraceptives is also demanding. }\end{array}$ \\
\hline
\end{tabular}

\section{Introduction}

Women living on the streets are vulnerable to various social, psychological, economic, and health related problems. Girls who work and live on the streets are exposed to the street subculture such as smoking, drug, alcohol, substance and sexual abuse, engaging in sexual activities or selling sex for survival that all put them at a higher risk of unintended pregnancies [1]. Homeless women are far more likely to experience violence of all sorts than women in general, ranging from two to four times more likely, depending on the violence type [2]. Researches reveal that women living on the streets are less likely to benefit from basic reproductive health services as living in the poorest segment, delivering and caring their children out of streets life [3]. $90 \%$ of maternal deaths could be pre vented with timely medical intervention [4]; therefore, the chances of death decrease considerably if women receive skilled maternal health care during delivery [5]. Being the poorest and marginalized segments of the society, pregnant women and infants living on the streets seem more vulnerable to maternal and child mortality and morbidity. Hence, it is important to assess the reproductive health seeking behavior of street women to understand access and use of antenatal and neonatal health care services.

Homeless women are the most marginalized segments of the society in terms of getting access to modern family planning services. Although Shashemene has plenty of NGOs working on improving the reproductive health situations of the town's population, their 
services have always been limited to serving the 'bar ladies', street females, long distance drivers, and people living with HIV/AIDS. The public sector, on the other hand, serves the 'mainstream' society. Provision of family planning service to the homeless women is, therefore, by far the most neglected issue for years. There is a widely held stereotype that these sections of the society do not have a need to the contraceptive methods by the NGOs, the public sector, and the wider society at large. The family planning needs of the target population has not been adequately researched which demands attention. Therefore, the present research attempted to assess the prevalence and determinants of contraceptive methods use among on-street women in the reproductive age ranges living on the streets of Shashemene, West Arsi zone, Oromia, Ethiopia.

\section{Methods and Materials}

\section{Study Design}

A cross-sectional study design was used in which the overall processes of data collection, analysis and write-up were taken place at a point of time between December, 2018 and February, 2019. Both descriptive and analytical research designs were intensively employed in order to effectively answer the proposed research questions. In its descriptive dimension, the research expressed existing realities and facts among the study's participants as revealed by them. On the other hand, the analytical part of the research considered the relationship between dependent and independent variables in order to seek responses for why things happened the way they appeared in the field.

Methods and data sources: Primary data were collected using survey, depth interview, case history, and non-participant observation methods (methodical triangulation). The survey method was used mainly to gather quantifiable data regarding the frequency of cases occurring and their patterns of distribution among the various segments of the study population. For this purpose, quantitative data were collected through a well-prepared interviewer-administered questionnaire. In addition, non-participant observation and case history methods were also used in order to enrich the qualitative data. Furthermore, existing literatures were intensively reviewed to supplement first-hand data sources. Data collectors were trained about the objectives and overall purpose of the research were made to be familiar with the data collection instruments and have been guided about how to best approach respondents and collect quality data.

Sample size and procedure: Data regarding the total number of on-street women, both in Shashemene town and West Arsi zone are hardly found not only in government offices but also in non-governmental organizations working in related issues in the town. This made it difficult to get access to the sample frame and hence, planning about the use of probability sampling techniques failed. The researcher resorted to purposive sampling method. First, Shashemene town was purposively selected due to the fact that homeless women prefer more of urban areas expecting better access to livelihood (getting more money by begging from densely populated area) and shelter. The survey purposively targeted homeless women within reproductive age range, including women that were either pregnant or carried one or more babies during the time of data collection. 148 respondents participated in the survey based on availability/judgmental selection criterion. For the in-depth interview and case history methods, data saturation determined the number of women to be participated in the interview. Therefore, sample size has not been predetermined and the researcher stopped as more redundant responses appeared and at a point where no more new data could be discovered. Accordingly, 15 women were participated. Consequently, data were collected from a total of 163 on-street women in the study area.

Data analysis: After all sorts of data were collected, data cleaning and organization was undertaken in order to check for completeness. The quantifiable data gathered through intervieweradministered questionnaire were then coded and entered into SPSS version 20 for further processing. Descriptive statistical tools, including frequency tables, Figures and percentages were utilized to present frequencies and differential distribution of cases across the various sub-groups within the survey participants. Furthermore, inferential statistical techniques such as correlations and multivariate linear regression were used in order to analyse the relationship between the dependent variable and the independent variables. In addition, qualitative data collected through depth interview and case history methods were first transcribed word for word (verbatim) and organized. Following this, themes were searched and identified in the data in order to analyze it against the specific research objectives. Finally, findings were presented in a narrative manner showing patterns in the analysis.

\section{Ethical Considerations}

The researcher has obtained ethical approval from the concerned body of Wolaita Sodo University. An informed consent was gained by informing the research participants about the objectives and rationale of undertaking the research. Furthermore, up on collecting data, the names of the research participants have notbeen written on the interviewer administered questionnaire and other checklists in order to keep their personal identity anonymous. The researcher further ensured this by not indicating the exact names of any of the respondents. Above all, each respondent was informed about the level of freedom that is provided in case one wants to withdraw from the research.

\section{Operational definitions:}

a. On-street women: women who make a living by begging on street sides, religious centers, and other mass concentration sites as a full time activity, those that have no formal homes instead use these sites as a shelter. In this document, both on-street women and homeless women have been frequently used interchangeably just to convey the same meaning. 
b. Rape: is defined as any act of penile penetration of the vagina or anal by force or by threat of harm, made when the victim/ woman is incapable of giving consent due to drug or intoxication of alcohol, mental illness, physical impairment or any other form disability to defend oneself.

\section{Results}

\section{Socio-demographic characteristics of respondents}

Table 1 shows the frequency distribution of respondents in terms of their socio-demographic characteristics. It is indicated in the table that $41.9 \%$ and $31.1 \%$ of respondents are in $31-40$ and 21-30 age ranges. This implies that the significant majority of on-street women in the study area are within the very fertile age segment. Regarding their marital status, it was found that $56.1 \%$ of them were currently married while only 13 replied that they are never married. Moreover, widowhood (20.3\%) and divorce, $14.9 \%$, have also been observed as other experiences of on-street mothers. As far as education is concerned, it has been found that 96 of 148 respondents never attended formal school, while insignificant proportion (1.4\%) responded to have completed high school education. Motherhood on the street can be more complicated when accompanied by the lack of basic literacy. Orthodox Christianity seems to have occupied the dominant share of religion among the respondents (55.4\%), followed by Islam (18.9\%).

Table 1: Socio-demographic distributions of respondents.

\begin{tabular}{|c|c|c|}
\hline Variables & Categories & Frequencies (\%) \\
\hline & $1-20$ & $8(5.4 \%)$ \\
\hline \multirow[t]{7}{*}{ Age } & $21-30$ & $46(31.1 \%)$ \\
\hline & $31-40$ & $62(41.9 \%)$ \\
\hline & $41-50$ & $11(7.4 \%)$ \\
\hline & $51-60$ & $12(8.1 \%)$ \\
\hline & $\geq 61$ & $9(6.1 \%)$ \\
\hline & Never married & $13(8.8 \%)$ \\
\hline & Married & $83(56.1 \%)$ \\
\hline \multirow[t]{3}{*}{ Marital status } & Divorced & $22(14.9 \%)$ \\
\hline & Widowed & $30(20.3 \%)$ \\
\hline & Never attended school & $96(64.9 \%)$ \\
\hline \multicolumn{3}{|l|}{ Education } \\
\hline & $1-4$ & $25(16.9 \%)$ \\
\hline & $5-8$ & $25(16.9 \%)$ \\
\hline & $9-10$ & $2(1.4 \%)$ \\
\hline & Orthodox Christian & $82(55.4 \%)$ \\
\hline \multirow[t]{4}{*}{ Religion } & Muslim & $28(18.9 \%)$ \\
\hline & Protestant & $21(14.2 \%)$ \\
\hline & Catholic & $17(11.5 \%)$ \\
\hline & Shashemene/West Arsi & $86(58.1 \%)$ \\
\hline \multicolumn{3}{|l|}{ Area/place of origin } \\
\hline & Came from other areas & $62(41.9 \%)$ \\
\hline
\end{tabular}

\begin{tabular}{|c|c|c|}
\hline Ethnicity & Oromo & $82(55.4 \%)$ \\
\hline & Amhara & $4(2.7 \%)$ \\
\hline $\begin{array}{c}\text { Number of years } \\
\text { stayed on street }\end{array}$ & SNNP & $62(41.9 \%)$ \\
\hline & $<1$ year & $15(10.1 \%)$ \\
\hline & $1-5$ years & $75(50.7 \%)$ \\
\hline & $6-10$ years & $36(24.3 \%)$ \\
\hline & $11-15$ years & $11(7.4 \%)$ \\
\hline & $16-20$ years & $8(5.4 \%)$ \\
\hline Total & $>21$ years & $3(2.0 \%)$ \\
\hline & & $148(100.0 \%)$ \\
\hline
\end{tabular}

Source: survey.

The table also contains statistical figures regarding the area of origin of survey respondents. It is shown that most of the respondents (58.1\%) are from around Shashemene town whereas the rest $41.9 \%$ reported to come from other neighboring regions and towns. Related to this is the ethnicity of respondents. Accordingly, survey respondents reported to belong to only three ethnic groups, i.e., Oromo, south nations, nationalities and peoples, and Amhara (55.4\%, 41.9, and 2.7\% respectively). Furthermore, respondents were asked to report how many years they stayed on the street and $50.1 \%$ revealed to have stayed for $1-5$ years, followed by $24.3 \%$ who stayed $6-10$ years. Only 3 respondents answered that they have stayed for more than 21 years on the street.

\section{Patterns and Experiences of Using Family Planning Methods}

Table 2 shows the frequency distribution of respondents in terms of their experiences of using family planning methods of all sorts. It is found that the slight majority of respondents $(50.7 \%)$ do not have knowledge of family planning methods. Moreover, $51.4 \%$ of them do not have the awareness that family planning methods prevent unintended pregnancies. This lack of awareness seems to have shadowed over the experiences of the survey participants in using family planning methods. As shown in Figure 1 below, 56.8\% of the respondents haven't ever used any family planning devices throughout their life time and only $36.5 \%$ responded to have used some kind of family planning method in the last 4 (four) months, taking the time of data collection as a reference. Furthermore, survey participants were also asked to furnish responses regarding the reason they failed to use family planning methods. From the 94 respondents who haven't ever used family planning methods, $62(41.9 \%)$ replied that it was because they do not know about it, followed by $12.2 \%$ who haven't used family planning methods for no reason. Lack of access, inability to afford one, and the absence of interest also hold some share in this regard $1.4 \%$, \& $4.1 \%$, respectively) as portrayed in Table 2 below. 
Figure 1. showing knowledge \& esperiences of using family planning methods

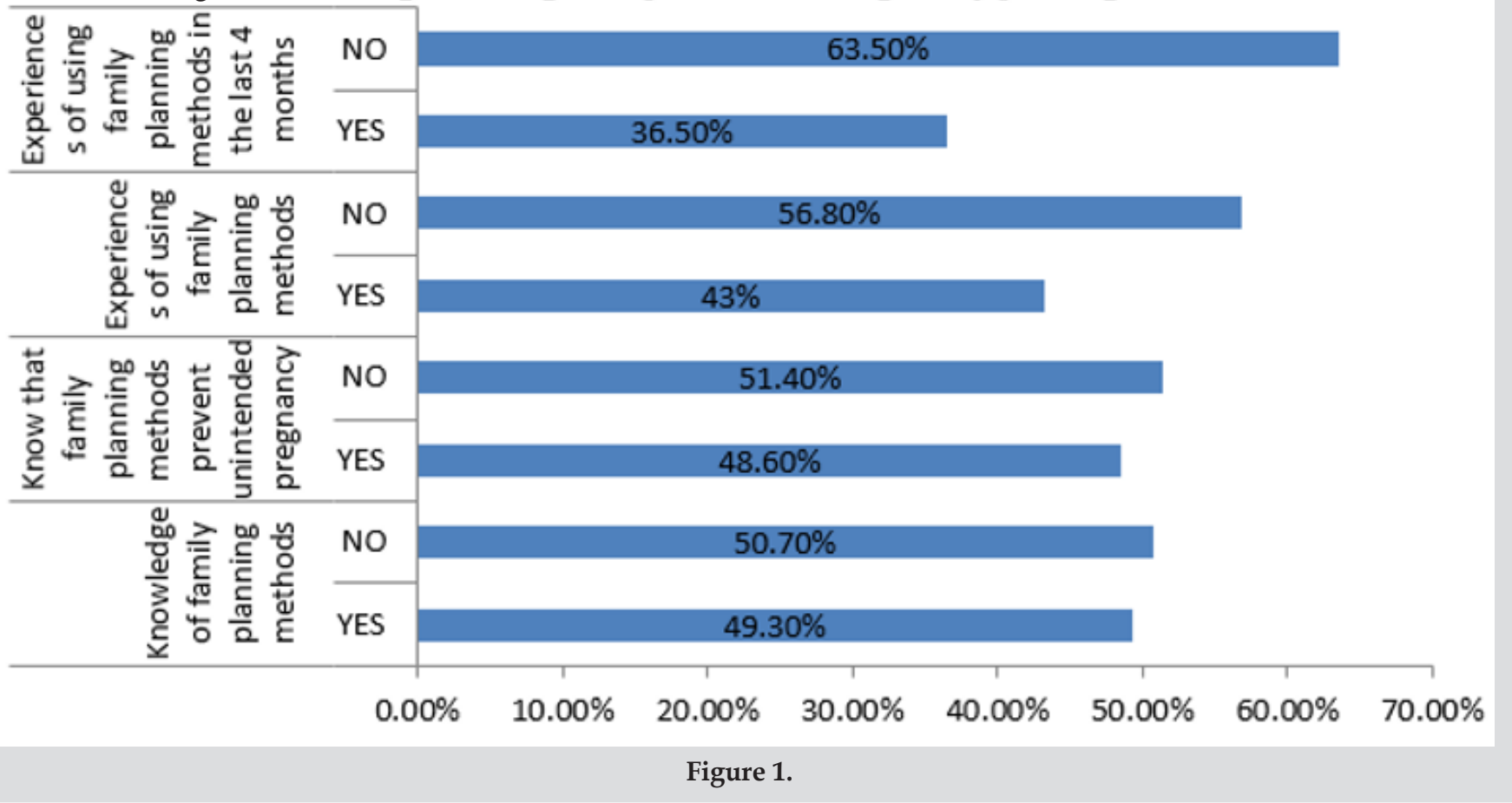

Table 2: Frequency distribution of respondents in terms of the experiences of using family planning methods.

\begin{tabular}{|c|c|c|c|}
\hline No. & Variable & Categories & Frequency (\%) \\
\hline \multirow{2}{*}{1.} & \multirow{2}{*}{ Knowledge of family planning methods } & YES & $73(49.3 \%)$ \\
\hline & & NO & $75(50.7 \%)$ \\
\hline \multirow{2}{*}{2.} & \multirow{2}{*}{$\begin{array}{l}\text { Knowledge that family planning methods prevent unintended } \\
\text { pregnancy }\end{array}$} & YES & $72(48.6 \%)$ \\
\hline & & NO & $76(51.4 \%)$ \\
\hline \multirow{2}{*}{3.} & \multirow{2}{*}{ Experiences of using family planning methods } & YES & $64(43.2 \%)$ \\
\hline & & NO & $84(56.8 \%)$ \\
\hline \multirow{2}{*}{4.} & \multirow{2}{*}{$\begin{array}{l}\text { Experiences of using family planning methods in the last } 4 \\
\text { months }\end{array}$} & YES & $54(36.5 \%)$ \\
\hline & & NO & $94(63.5 \%)$ \\
\hline \multicolumn{3}{|c|}{ Total } & $148(100.0 \%)$ \\
\hline \multirow{5}{*}{5.} & & Lack of access & $2(1.4 \%)$ \\
\hline & Reason for not using family planning methods? & Lack of interest & $6(4.1 \%)$ \\
\hline & & Couldn't afford & $6(4.1 \%)$ \\
\hline & & Lack of knowledge & $62(41.9 \%)$ \\
\hline & & No reason & $18(12.2 \%)$ \\
\hline
\end{tabular}




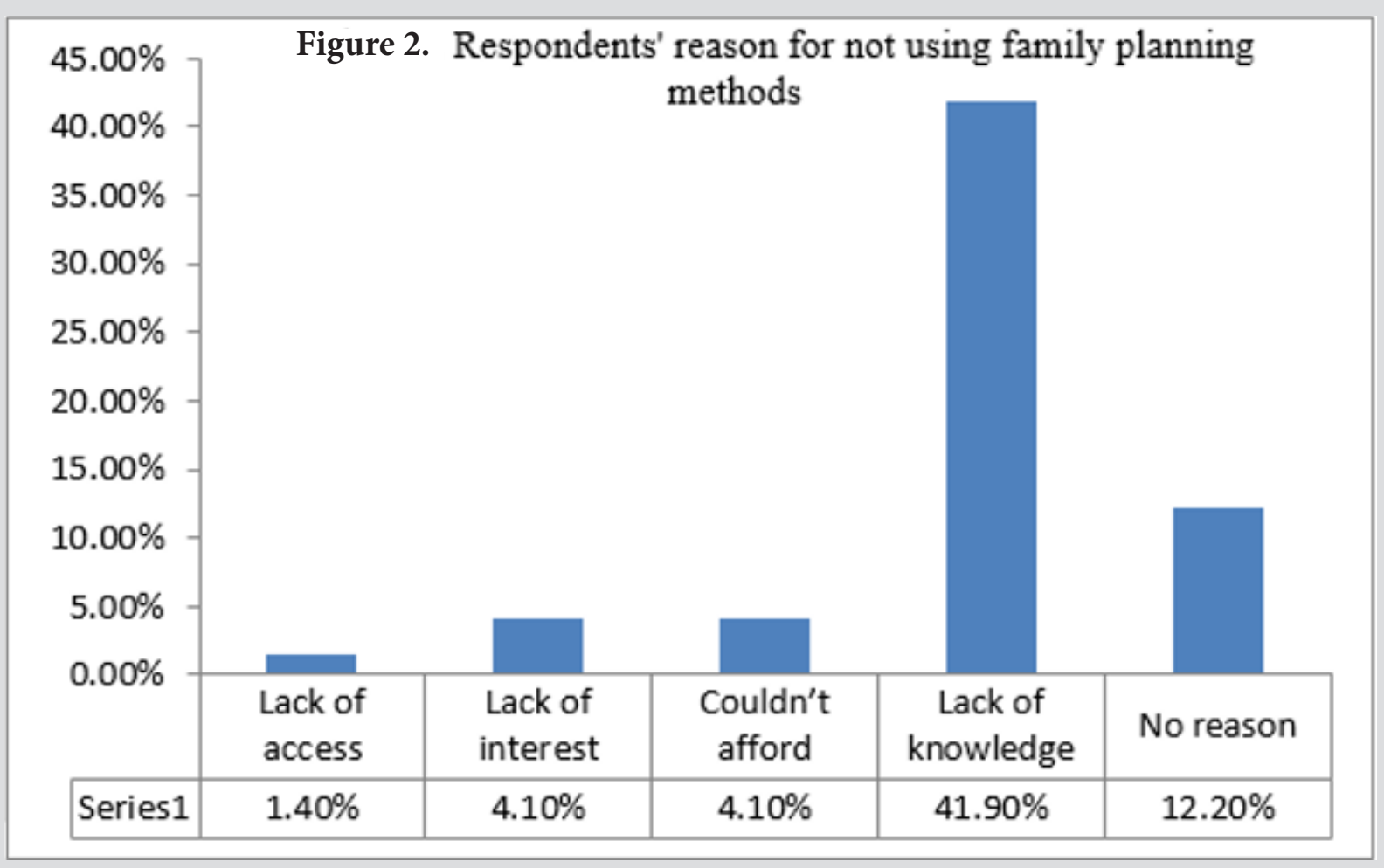

Figure 2.

Data presented in table furnished us with an interesting insight in that the experience of using family planning methods among the target population in the study area is low which might have emanated from the fact that there is a very low level of awareness regarding the subject. Table 3 is an attempt to present data to check whether or not respondents' experience of using family planning methods is associated to their background characteristics. According to the data, the use of family planning methods is significantly associated to age $(.202, \mathrm{P}<0.05,95 \% \mathrm{CI})$, the number of children a woman gave and background characteristics

\begin{tabular}{|c|c|c|c|c|c|c|c|c|c|}
\hline & & Age & $\begin{array}{l}\text { Marital } \\
\text { status }\end{array}$ & $\begin{array}{l}\text { Area of } \\
\text { origin }\end{array}$ & Ethnicity & Education & Religion & $\begin{array}{c}\text { No. of } \\
\text { children }\end{array}$ & $\begin{array}{c}\text { using family } \\
\text { planning methods }\end{array}$ \\
\hline \multirow{3}{*}{ Age } & $\begin{array}{c}\text { Pearson } \\
\text { Correlation }\end{array}$ & 1 & $.477^{* *}$ & -0.09 & 0.006 & $-.280^{* *}$ & -0.032 & $.303^{* *}$ & $.202^{*}$ \\
\hline & Sig. (2-tailed) & & 0 & 0.275 & 0.945 & 0.001 & 0.704 & 0 & 0.014 \\
\hline & $\mathrm{N}$ & 148 & 148 & 148 & 148 & 148 & 148 & 148 & 148 \\
\hline \multirow{3}{*}{ Marital status } & $\begin{array}{c}\text { Pearson } \\
\text { Correlation }\end{array}$ & $.477^{* *}$ & 1 & 0.031 & 0.04 & -0.152 & 0.081 & $.304^{* *}$ & 0.132 \\
\hline & Sig. (2-tailed) & 0 & & 0.704 & 0.626 & 0.065 & 0.327 & 0 & 0.109 \\
\hline & $\mathrm{N}$ & 148 & 148 & 148 & 148 & 148 & 148 & 148 & 148 \\
\hline \multirow{3}{*}{ Area of origin } & $\begin{array}{c}\text { Pearson } \\
\text { Correlation }\end{array}$ & -0.09 & 0.031 & 1 & $.860^{* *}$ & 0.119 & $-.242^{* *}$ & -0.016 & -0.005 \\
\hline & Sig. (2-tailed) & 0.275 & 0.704 & & 0 & 0.151 & 0.003 & 0.85 & 0.95 \\
\hline & $\mathrm{N}$ & 148 & 148 & 148 & 148 & 148 & 148 & 148 & 148 \\
\hline \multirow{3}{*}{ Ethnicity } & $\begin{array}{c}\text { Pearson } \\
\text { Correlation }\end{array}$ & 0.006 & 0.04 & $.860^{* *}$ & 1 & 0.059 & $-.220^{* *}$ & -0.093 & -0.023 \\
\hline & Sig. (2-tailed) & 0.945 & 0.626 & 0 & & 0.478 & 0.007 & 0.258 & 0.781 \\
\hline & $\mathrm{N}$ & 148 & 148 & 148 & 148 & 148 & 148 & 148 & 148 \\
\hline
\end{tabular}

birth (.189, $\mathrm{P}<.021,95 \% \mathrm{CI})$, and education $(-.384, \mathrm{P}<0.01,90 \% \mathrm{CI})$. Once again, the direction of association between education and use of family planning methods is negative meaning that as one gets more and more educated, she tend to be less prone to use family planning methods. Age and number of children are positively correlated implying that the older the woman gets and the more

Table 3: Correlation between use of family planning methods children she bears, the more she use family planning methods. 


\begin{tabular}{|c|c|c|c|c|c|c|c|c|c|}
\hline \multirow{3}{*}{ Education } & $\begin{array}{l}\text { Pearson } \\
\text { Correlation }\end{array}$ & $-.280^{* *}$ & -0.152 & 0.119 & 0.059 & 1 & -0.08 & $-.268^{* *}$ & $-.384^{* *}$ \\
\hline & Sig. (2-tailed) & 0.001 & 0.065 & 0.151 & 0.478 & & 0.335 & 0.001 & 0 \\
\hline & $\mathrm{N}$ & 148 & 148 & 148 & 148 & 148 & 148 & 148 & 148 \\
\hline \multirow{3}{*}{ Religion } & $\begin{array}{c}\text { Pearson } \\
\text { Correlation }\end{array}$ & -0.032 & 0.081 & $-.242^{* *}$ & $-.220^{* *}$ & -0.08 & 1 & 0.008 & 0.081 \\
\hline & Sig. (2-tailed) & 0.704 & 0.327 & 0.003 & 0.007 & 0.335 & & 0.921 & 0.325 \\
\hline & $\mathrm{N}$ & 148 & 148 & 148 & 148 & 148 & 148 & 148 & 148 \\
\hline \multirow{3}{*}{ No. of children } & $\begin{array}{l}\text { Pearson } \\
\text { Correlation }\end{array}$ & $.303^{* *}$ & $.304^{* *}$ & -0.016 & -0.093 & $-.268^{* *}$ & 0.008 & 1 & $.189 *$ \\
\hline & Sig. (2-tailed) & 0 & 0 & 0.85 & 0.258 & 0.001 & 0.921 & & 0.021 \\
\hline & $\mathrm{N}$ & 148 & 148 & 148 & 148 & 148 & 148 & 148 & 148 \\
\hline \multirow{3}{*}{$\begin{array}{l}\text { Using family } \\
\text { planning } \\
\text { methods }\end{array}$} & $\begin{array}{l}\text { Pearson } \\
\text { Correlation }\end{array}$ & $.202^{*}$ & 0.132 & -0.005 & -0.023 & $-.384^{* *}$ & 0.081 & $.189^{*}$ & 1 \\
\hline & Sig. (2-tailed) & 0.014 & 0.109 & 0.95 & 0.781 & 0 & 0.325 & 0.021 & \\
\hline & $\mathrm{N}$ & 148 & 148 & 148 & 148 & 148 & 148 & 148 & 148 \\
\hline
\end{tabular}

\section{The Need to Use Family Planning Methods}

Figure 3 shows the distribution of respondents in terms of their need to use family planning methods. It reveals how much on-street women were showing interest to consume some kind of family planning methods. In the Figure, data showed that the significant majority of respondents were needy of the methods. It was found that $70.9 \%$ of them replied that they need to use family planning methods if they are provided with the access. The presence of a high demand for using the methods calls for both governmental and non-governmental organizations to make interventions in the area. Findings of depth interview also revealed low level of awareness about contraceptive methods and the experience of using one. Few assume that family planning exists only in the form of needle injection. Hence, this created a sense of fear that it might be painful. Many also revealed that they are not currently using contraceptive methods. One factor has been identified to be the higher prevalence of HIV/AIDS among the research participants. In fact, HIV/AIDS has a mix of both positive and negative implications on the patterns of using contraceptive methods among the research participants.

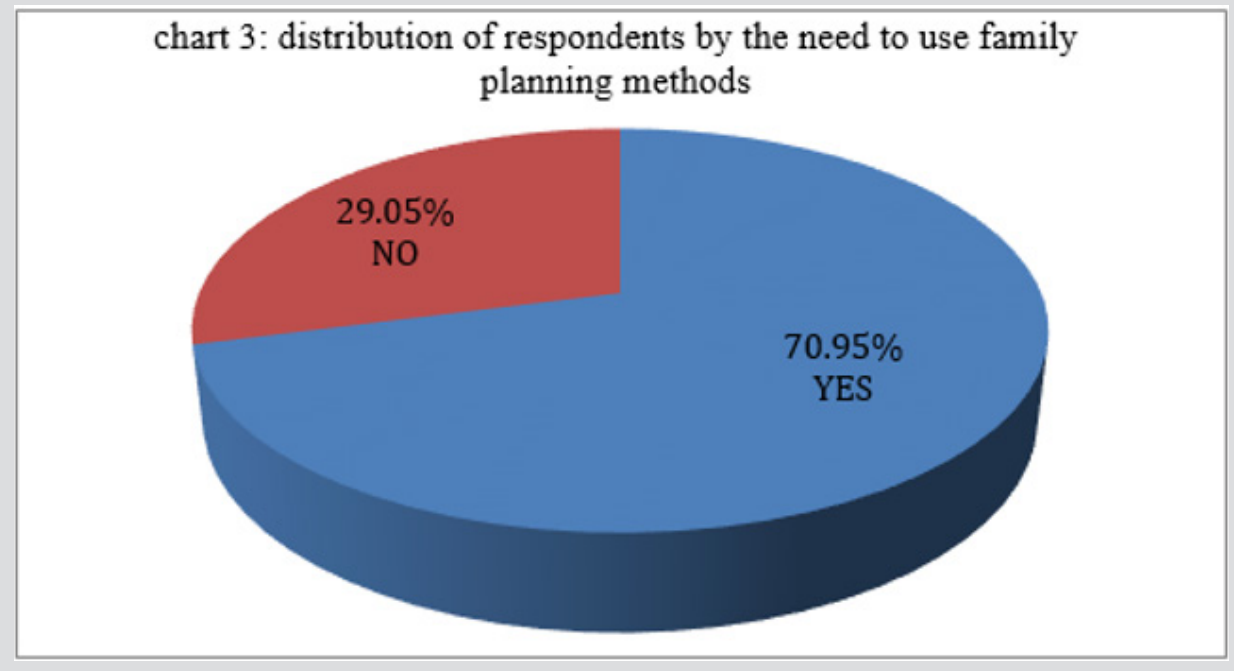

Figure 3.

For some women, HIV positive status served as a discouraging factor in the sense that it made them lose hopes and get reluctant about their entire life. For others, a monthly visit of health care facilities to get ART drugs served as a latent function to have an easy access to both physicians' counseling about contraception and the devices as well. The experience of not using contraceptive devices among some research participants has been an issue of ignorance: I neither make sexual intercourse, nor bother about the use of family planning methods anymore. The use of contraception for some on- street women has been a matter of compulsion from networks of social support groups. It was my sister who forced me to go to a hospital and to be injected a family planning method two years ago confirms the reality.

\section{Case}

Meseret is a 34 years old adult woman using the street both as a shelter and a means of making a living. She came from Wolaita and had been on the street since her early childhood. She has never 
had a child nor she ever been pregnant. She used to date a boy from Hawassa area, who left her accidentally. Meseret was extremely eager to have a baby for long. Therefore, she has never been using contraceptive methods. She believes that children are gift of God. She also thinks that a person should replace its offspring and that this is the meaning of worldly life. She has repeatedly tried to conceive a baby to the extent of not using condoms even when making sexual intercourses with different individuals. Unfortunately, Meseret was not able to bear a child yet.

In the mid of trying to get a child, Meseret realized that she was infected by HIV/AIDS. Meseret is now so desperate that she gave up the hope of having children. Especially after knowing her HIV status, she has become highly careless about her existing life and the future. She has slept in a jungle in order to be eaten by a hyena. Added to her previous expectation of conceiving a baby, her health condition made her to lose interest of using family planning methods of all sorts. She complains about her body weight to be inconvenient for using contraceptive methods.

\section{Discussion}

Knowledge of family planning methods and the experiences of using one were moderately low among the homeless women, according to the findings of the present study. Whereas $49.3 \%$ have ever heard about family planning methods, $48.6 \%$ responded that they know the fact that family planning methods can prevent unwanted pregnancies. In the present study, $43.2 \%$ had the experiences of using one or more types of family planning methods. Part of these findings are consistent with the findings of [3] and inconsistent in some other ways. For instance, in his study of awareness and utilization of modern contraceptives among street women in North-west Ethiopia, he found that $90.7 \%$ have ever heard about modern contraceptives, a finding that actually remained inconsistent from the finding of the present study (49.3\%). According to Berihun's study, 47.1\% have ever used modern contraceptives which is somewhat consistent with the present research (43.2\%). Findings from unpublished thesis by [6] showed that the use of modern conraceptive among the homeless women in Addis Ababa was good.

According to the study, $81.9 \%$ of respondents have ever used contraceptive method and $71.3 \%$ were using contraceptives during the time of survey. Hence, the use of family planning merhods among homeless women in Shashemene is low compared to other areas. The findings of [7] revealed that $46 \%$ of sexually experienced females in Ethiopia have ever used family planning methods. Therfore, when compared with the status- quo in the general population, the situation of street women in relation to family planning methods cannot be undermined. The reason for not using modern contraception has been found to be the lack of knowledge for the majority of the homeless women (41.9\%) in the present study. Furthermore, the use of family planning methods has been found to be significantly associated to age $(.202, \mathrm{P}<0.05,95 \% \mathrm{CI})$, the number of children a woman gave birth (.189, $\mathrm{P}<.021,95 \% \mathrm{CI})$, and education $(-.384, \mathrm{P}<0.01,90 \% \mathrm{CI})$. In the findings of [3] too, age, marital status and family size were found to be determinants of the use of modern contraceptives. [8], identified age at first marriage, being educated, number of living children, exposure to mass media, being employed, having educated partners, and having been informed about contraceptive use at health care facilities to be positively associated with contraceptive use. In contrast, being older age, a rural resident, being a muslim, belonging to the Afar or Somali ethnic group, desiring numerious children, having hasbands desiring numerious children, and abortion experiences to be negatively associated with contraceptive use among women in reproductive age group in Ethiopia.

\section{Conclusion and Recommendation}

Awareness regarding contraceptive methods among on-street women is low in Shashemene town, west Arsi zone, Ethiopia. This low level of awareness is accompanied by the lower experiences of using one or more types of contraceptive methods among the study's population. Furthermore, the problem has been aggravated by the unprecedently high prevalence rate of HIV/AIDS and almost a negligible level of basic literacy among the target groups. Unless immediate remedial action is taken by the concerned governmental and non-governmental organizations, on-street women in Shashemene town will continue with their high fertility rates, making the vicious cycle of poverty to sustain.

\section{Reference}

1. FSCE (2003) Sample survey about street children in eight major towns of Ethiopia.

2. Goodman LA, Thompson KM, Weinfurt K, Corl S, Acker P, et al. (1999) Reliability of reports of violent victimization and posttraumatic stress disorder among men and women with serious mental illness. J Trauma Stress 12(4): 587-599.

3. Berihun Megabiaw (2012) Awareness and utilization of modern contraceptives among street women in North-West Ethiopia. BMC Women's Health 12: 31.

4. Ronsmans C, Graham WJ (2006) Maternal Mortality: Who, when, where, and why. Lancet 368(9542): 1189-1200.

5. (2011) World Health Organization (WHO). World Health Statistics 2011. Geneva: WHO.

6. Beza Alemayehu (2018) Prevalence and Predictors of Modern Contraceptive Use Among Homeless Women in Addis Ababa: The Health Belief Model Perspective. Unpublished thesis Submitted to Addis Ababa University College of Health Sciences School of Public Health in Partial Fulfillment of the Requirement for the Degree of Master of Public Health.

7. (2010) Population Council \& UNFPA, Ethiopian Young Adult Survey: A study in seven regions Central statistical authority (CSA) \& Ethiopian demographic \& health survey 2011 Addis Ababa Ethiopia.

8. Fentanesh Nibret, Peter AM Nitenda (2016) Factors associated with contraceptive use and intention to use contraceptives among married women in Ethiopia. Journal Women \& Health 56(1): 1-22. 
ISSN: 2574-1241

DOI: 10.26717/BJSTR.2019.20.003476

Bewunetu Zewude G. Biomed J Sci \& Tech Res

(c) (P) This work is licensed under Creative

Submission Link: https://biomedres.us/submit-manuscript.php

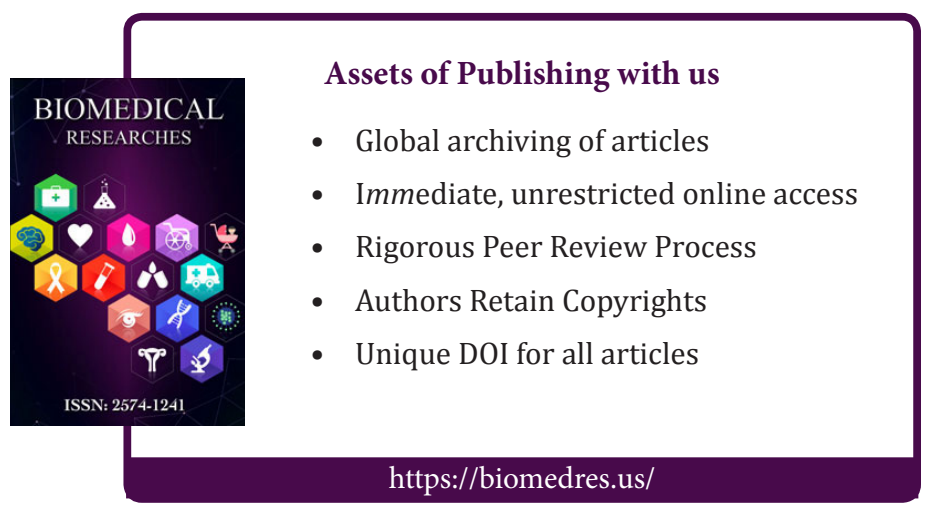

